\title{
ProduCt INNOVATION INFLUENCE ON Production Organization
}

\author{
Ing. Patrik Polášek, Doc. Ing. Michal Šimon, Ph.D.
}
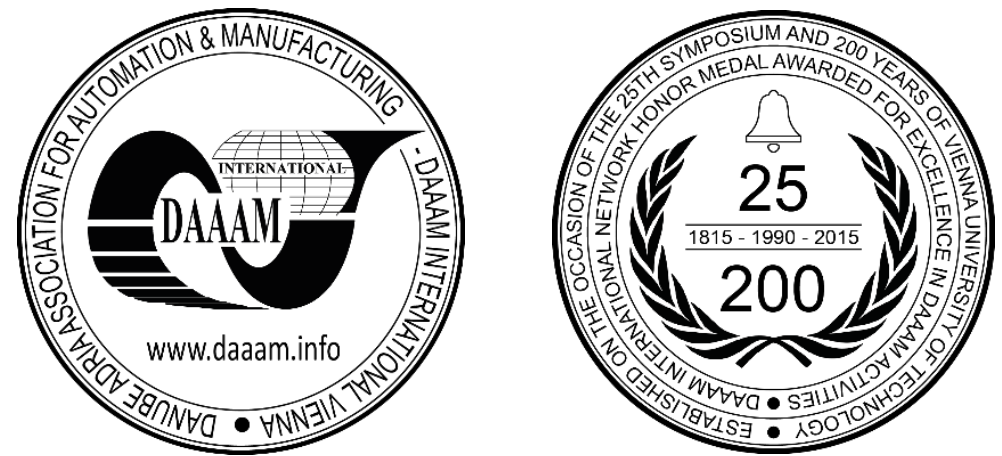

This Publication has to be referred as: Polasek, P[atrik] \& Simon, M[ichal] (2018). Product Innovation Influence on Production Organization, Proceedings of the 29th DAAAM International Symposium, pp.0548-0552, B. Katalinic (Ed.), Published by DAAAM International, ISBN 978-3-902734-20-4, ISSN 1726-9679, Vienna, Austria DOI: $10.2507 / 29$ th.daaam.proceedings.079

\begin{abstract}
This article deals with individual product innovations and their influence on production workplace and the technological production process. This work firstly deals with the current scientific knowledge, followed by the research itself, which defines the individuals inputs - product innovations and then the individual links between these innovations and the technological production process and workplace organization. In conclusion, the solution is outlined in the form of a complex model, that clearly determines which types od product innovations influences the technological production process and workplace organization, and in what way.
\end{abstract}

Keywords: innovation; innovation model; technological process; workplace organization; working environment

\section{Introduction}

Currently the market is constantly changing and customer needs changes as well. Who reacts first and submit to customer product, which meets customer's requirements, they will win. Manufacturers then have to constantly react to new customer demands and at the same time reacts to products supplied by competitors. And accurately product innovation can distinguish the company from others. Innovations helps increase profits and builds company so that it does not grow older, but instead builds permanent value for its customers. [4] Companies must deliberately looking for sources of innovation, changes and sign of change, indicating the potencial for successful innovations. And they need to know and use principles of successful innovations. [6]

The aim of this article is to outline problematics of product innovations related to their production realization, and to propose a solution, that will be realized in next phase of research. Next step of research will be design of model - the system where according defined input (product innovation), we will be able to deduce the need to change the layout of the workplace, with take into account the technological process of production.

The whole this research will be realized on real products, in real production organization. For obvious reasons, is it not possible to focus on the entire spectrum of products, and therefore is also necessary to identify the basic set of products, that must meet certain specified conditions. For this research is used system approach, which is a creative way of thinking applied to human activities linked with problem solving, that respects basic system attributes. [7] Cooper (1995) [8] defines scientific research as a systematic, controlled, empirical and critical study of natural phenomena and their supposed relationships. 
All outputs of this research will help to raise awareness of product innovations issues on the one hand, but also will mainly define a complex model, that uniquely determines the dependence of product innovation on the technological process of production and workplace organization.

The next step of this research is the verification of results on other products, that meets defined conditions. These products will be selected from Czech different production companies, like TUP Bohemia, which produces car interior products, Carrier, which deals with the production of cooling technology and from Grammer company, which deals with car inside covers.

\section{Current state of scientific knowledge}

All companies and organizations need to be innovative, because then they will secure future earnings. Most companies, especially small and medium-sized ones, are not always aware of what innovation is and how to drive it. Innovations are not prerogative of high-tech companies. Every individual person, every company in each industry can be innovative. Innovation is a process, that can be learned. [3]

Innovations are linked to a number of theoretical concepts - what is innovation, what are the main types and characteristics of innovation, how innovation can be managed, etc. There are different views, opinions, approaches, there is no one theory of innovation. [1]

The basic definition of innovation indicating the OECD document "Oslo Manual (Innovation)". The main division is to technical and non-technical innovation.

Technical innovations are product and technological innovations, consisting of the introduction of new products and technologies and the substantial technical improvement of the manufactured products and used technologies. [2] Innovation is considered as realized by implementation of the new or improved product on the marked or the use of new or improved production technology. We have to not forget also for role of logistics. The role of logistics is steadily increasing of value of the supplied product and the level of the delivery services. [5]

One of the most important characteristics of innovation is that it is a continuous process. The financial performance of company is therefore heavily dependent on successful innovation. Innovation is the driver key of economic development and brings additional benefits. Ideas and discoveries increase our standard of living. Innovation can also help improve safety, health care, product quality and more environmentally friendly products. Innovation has enabled a significant increase of productivity and has significantly changed the way our life. [1]

This research will come out and use the theory of innovation according Prof. Valenta, who divided the innovations into several groups and orders. This research will focus only on innovation of 1 to 5 orders. Prof. Valenta understands innovation as any change in the internal structure of the production organism. This is therefore any transition from the original to the new state. The term production organism is a generic designation for the organizational unit in which the process is applied with the application of the technique. The production organism can be a workshop, a plant, an enterprise, a research institute, etc. [9]

\begin{tabular}{|l|l|l|l|l|}
\hline $\begin{array}{l}\text { Innovation } \\
\text { order }\end{array}$ & Designation & What keeps & What changes & Example \\
\hline $\mathbf{1}$ & Quantity change & All features & Frequency of factors & Other workforce \\
\hline $\mathbf{2}$ & Intensity & $\begin{array}{l}\text { Quality and } \\
\text { interconnection }\end{array}$ & Speed of operations & Increased belt speed \\
\hline $\mathbf{3}$ & Reorganization & Quality features & Division of activities & Move operations \\
\hline $\mathbf{4}$ & $\begin{array}{l}\text { Qualitative } \\
\text { adaptations }\end{array}$ & Quality for user & Link to other factors & Technological design \\
\hline $\mathbf{5}$ & Variant & $\begin{array}{l}\text { Constructional } \\
\text { solutions }\end{array}$ & Partial quality & Faster machine \\
\hline
\end{tabular}

Table 1. Innovation orders by Prof. Valenta [4]

\section{Research investigation}

For each research, it is crucial to determine the range of sampling at the beginning. Logically, it can be deduced from the general statistics, that the more statistical units are included in the file, the more accurate the information will be. This research will be solved by the technique of deliberate selection, since the use is based on the predetermined focus of the research.

Limitations of this research are given by the products themselves, which have to meet the conditions defined bellow and by research assignment itself. Research is also limited by the number od products surveyed, which will be approximately 40 . 
In this research we cannot focus on the whole spectrum of all products, because exists countless types of products, so it is necessary to specify and identify a core set of products, that must meet certain specified conditions. These conditions were picked up with respect to the objectives of the research.

Products in this research must therefore meets following conditions:

- $\quad$ Product must be up to $1 \mathrm{~m}$ size

- Maximum product weight up to $20 \mathrm{~kg}$

- $\quad$ Product must be composed of several components

A basic data set was obtained from automotive company Hutchinson, a supplier of rubber parts for the automotive industry. Products are associated with some of the innovation orders, which are mentioned above. Bellow is an example of one selected product.

\begin{tabular}{|l|l|l|}
\hline Description of innovation & $\begin{array}{l}\text { Glue change - faster drying, shorter machine time } \\
\text { Changing rotation of glued buckles, resizing glued } \\
\text { buckles }\end{array}$ \\
\cline { 2 - 3 } & $\begin{array}{l}\text { Increase machine capacity } \\
\text { Improved customer assembly }\end{array}$ \\
\hline Product description & $\begin{array}{l}\text { Simple air hose with marking and glued clips } \\
\text { Order 5 - Variant }\end{array}$ \\
\hline Innovation order & \\
\hline
\end{tabular}

Table 2. Example of real product

From selected set of products is defined link between the selected innovation orders and the technological process. The relationship between innovation orders of the selected products and their technological process is summarized in the following table (Table 3), in which is defined technological process of production, which is same for all selected products. Innovative orders of products can influence the process technological process (ITP) or change it at the same time (CTP). Influencing and changing the technological process is not the same. By influencing is meant a change, that does not change technological process itself. For example, change of the marking shape - the marking template or plate must be modified, but the technological process itself is not changed.

\begin{tabular}{|c|c|c|c|c|c|c|}
\hline & & & Innovatio & orders by & rof. Valenta & \\
\hline Technological & rocess & ITP/ & 1 & 2 & 4 & 5 \\
\hline & Control/ & ITP & $\mathrm{x}$ & & & $\mathrm{x}$ \\
\hline Input control & Packaging/Expedition & CTP & & & & \\
\hline & & ITP & $\mathrm{x}$ & & & $\mathrm{x}$ \\
\hline Extrusions & & CTP & & & & $\mathrm{x}$ \\
\hline$N_{1} \quad 0^{\circ}$ & Tolond & ITP & $\mathrm{x}$ & & & $\mathrm{x}$ \\
\hline Vulcanızation & Technological processes & CTP & & & & $\mathrm{x}$ \\
\hline & & ITP & $\mathrm{x}$ & & & $\mathrm{x}$ \\
\hline Washing & & CTP & & & & \\
\hline 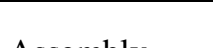 & A & ITP & $\mathrm{x}$ & $\mathrm{x}$ & $\mathrm{x}$ & $\mathrm{x}$ \\
\hline Assembly & Assembly processes & CTP & & & $\mathrm{x}$ & $\mathrm{x}$ \\
\hline Dolorinct & Control/ & ITP & $\mathrm{x}$ & & & $\mathrm{x}$ \\
\hline Packaging & Packaging/Expedition & CTP & & & & \\
\hline
\end{tabular}

Table 3. An example of the link between the innovations and the technological process

Based on the evaluation and subsequent analysis between the selected products and their influence on the technological process, it can be concluded, that a general link can be established between the selected innovation orders of products and the technological process of production. The next step is to define the relationship between the change of the technological process of production and the organization of the workplace (CWL - change of workplace layout). An example of the evaluation you can see bellow (Table 4). 


\begin{tabular}{|c|c|c|c|c|c|c|c|c|}
\hline \multirow{3}{*}{ 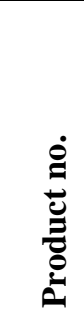 } & \multirow{3}{*}{ 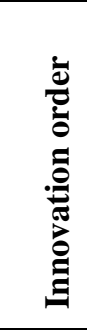 } & & \multicolumn{6}{|c|}{ Technological process of production } \\
\hline & & & 豆 & 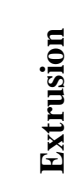 & 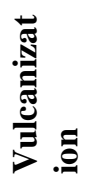 & 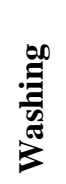 & $\begin{array}{l}\frac{\lambda}{0} \\
\frac{0}{0} \\
\frac{0}{2} \\
\frac{n}{4}\end{array}$ & 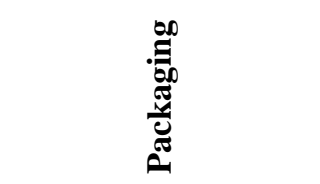 \\
\hline & & & $\begin{array}{l}\text { Control/ } \\
\text { Packaging/Expedition }\end{array}$ & \multicolumn{3}{|c|}{ Technological processes } & $\begin{array}{l}\text { Assembly } \\
\text { processes }\end{array}$ & $\begin{array}{l}\text { Control/ } \\
\text { Packaging/Expedition }\end{array}$ \\
\hline \multirow{3}{*}{1} & \multirow{3}{*}{1} & ITP & $\mathrm{X}$ & $\mathrm{X}$ & $\mathrm{X}$ & $\mathrm{X}$ & $\mathrm{X}$ & $\mathrm{X}$ \\
\hline & & CTP & & & & & & \\
\hline & & CWL & & & & & $\mathrm{X}$ & \\
\hline \multirow{3}{*}{2} & \multirow{3}{*}{1} & ITP & $\mathrm{X}$ & $\mathrm{X}$ & $\mathrm{X}$ & $\mathrm{X}$ & $\mathrm{X}$ & $\mathrm{X}$ \\
\hline & & CTP & & & & & & \\
\hline & & CWL & & & & & & \\
\hline \multirow{3}{*}{3} & \multirow{3}{*}{4} & ITP & & & & & $\mathrm{X}$ & \\
\hline & & CTP & & & & & $\mathrm{X}$ & \\
\hline & & CWL & & & & & $\mathrm{X}$ & \\
\hline \multirow{3}{*}{4} & \multirow{3}{*}{5} & ITP & & $\mathrm{X}$ & $\mathrm{X}$ & & $\mathrm{X}$ & $\mathrm{X}$ \\
\hline & & CTP & & & & & & \\
\hline & & CWL & & & $\mathrm{X}$ & & & \\
\hline
\end{tabular}

Table 4. Workplace layout change due to product innovation

The most significant influence of the technological process of production on the workplace layout is, of course, in the assembly process of product itself. For each sub-operation is needed individual workplace, which is specific to the type of assembly. Based on the evaluation and subsequent analysis between the selected products, their influence on the technological process of production and the workplace layout, it can be concluded, that a general link can be defined between the change of technological process of production due to the added product innovation and the workplace organization. You can see this general link in Fig. 1.

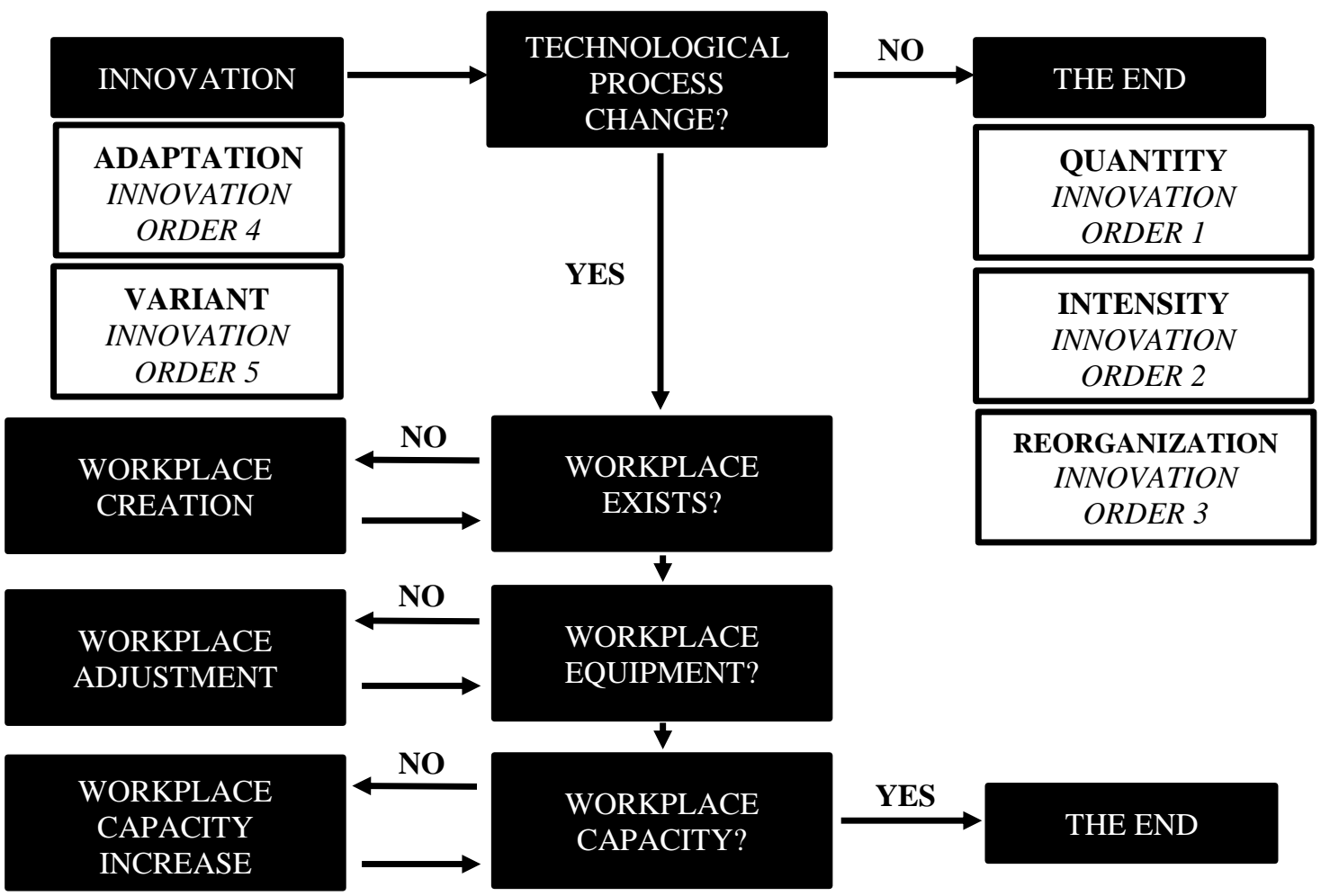

Fig. 1. The link between the technological process and the workplace organization

For technological process change have influence only production innovations of fourth and five order. Innovation of the first, second and third orders does not affect the change of technological process of production. If there has been a change in the technological process of production due to product innovation, it must be determined whether there is a workplace on which this innovation can take place. 
If such a workplace does not exist, it has to decide whether a completely new workplace will be created or whether any existing ones will already be adjusted to the production needs according to the changed technological process of production. It is also necessary to assess whether the workplace, existing, new or modified, has sufficient equipment to implement the product innovation. If the workplace does not have such equipment, it needs to be equipment secured. The final step is to determine, if we are able to meet the production requirements at the workplace with the equipment. Means if the workplace capacity is sufficient. If not, the workplace must be modified to meet production requirements.

\section{Outline of further research work}

The next stage of this research is the verification of results on other products, that meets defined conditions. These products will be selected from Czech different production companies, like TUP Bohemia, which produces car interior products, Carrier, which deals with the production of cooling technology and from Grammer company, which deals with car inside covers. The results and outcome of this research will be the model or system that will determine the need for changing the working environment according to the degree of innovation.

This research solves from wide area of innovation management only the problem of the connection of product innovations with the change of the technological process of production and the change of the workplace organization. The result will be an important key to opening up the possibilities for solving this kind of innovation issues. All knowledge can be used in all factories and have an overview of what factors can be influenced by innovation activities, how the technological process of production changes, and whether product innovation will affect the workplace layout.

\section{Conclusion}

This research or its next follow up, outlines the product innovations and its link with the production system. So, before implementing the product portfolio itself, it can be ascertained whether this product innovation will affect the technological process of production and how. It can also be find if there is need to create a new workplace where new innovations will be manufactured or assembled.

Companies also needs to realize that any minor change in the production system means in most cases the modification of existing documentation etc., which is usually very extensive. The type of production that is defined for a given product also has a big influence on the change in work organization due to product innovation. So whether it is one piece flow or batch production.

Companies must realize that every slice of product innovation gives them a competitive advantage. The vast majority of companies that are not self-sufficient, or who does not produce their own products in their finished products, have to meet their customers - in the end, and thus avoid any change to the products the customer wants to do.

\section{References}

[1] Online manual for innovation, Available from: http://www.innosupport.net

[2] Oslo manual, OECD/EC (Eurostat) (2012). Available from: http://dx.doi.org/10.1787/9789264013100-en

[3] Bartes, F. (2008). Innovation in company, Akademické nakladatelství CERM, ISBN 978-80-214-3634-3.

[4] Heřman, J. (2002). Industrial innovations. Praha. ISBN 978-80-245-1445-1

[5] Cibulka, V. (2010). Integrated optimization of process innovation in industrial enterprice as equipment of ensuring and increasing of supplied goods value. 21st International DAAAM Symphosium, Vienna, Austria. ISBN 978-3901509-73-5

[6] P.F.Drucker Inovace a podnikavost, Management Press, Praha 1993. ISBN 80-85603-29-2

[7] Knapp, V. Úvod do vědecké práce. 1 vyd. Brno. Univerzita J. E. Purkyně, 1981. ISBN 80-86432-54-8

[8] Chráska, M., Metody pedagogického výzkumu, Grada. Praha 2007. ISBN: 978-80-247-5326-3

[9] Chundela, L. Ergonomie, ČVUT, Praha, 2005. ISBN 978-80-01-0517-3 